These two qualitative papers contribute to the development of new and innovative models of providing aspects of COPD care and shared decision-making. Their findings suggest that there is a need for ongoing debate regarding workforce issues and the development of appropriate competencies even in the highly centralised UK National Health Service. However, there are also other models - for example, the use of a hospital-based dedicated healthcare professional to promote discussion of ACP with patients directly ('Respecting Patient Choices $^{\prime 12}$ ) currently in use in Australia and the USA. The role of other models should also be investigated.

Nevertheless, given the growing burden of disease from COPD resulting from changing demographics, ${ }^{13}$ it is clear from both papers ${ }^{1,2}$ that patient choices will be necessary, and that changes to traditional health service delivery (including the roles of health service providers) will be required, in order to accommodate the projected increase in demand.

Conflicts of interest DG is an Associate Editor of the $P C R J$, but was not involved in the editorial review of, nor the decision to publish, this article. JW and $\mathrm{CR}$ declare that they have no conflicts of interest in relation to this article.

Commissioned article; not externally peer-reviewed; accepted 16th July 2012; online 26 July 2012

(C) 2012 Primary Care Respiratory Society UK. All rights reserved

http://dx.doi.org/10.4104/pcrj.2012.00067

Prim Care Respir J 2012; 21(3): 241-242

\section{References}

1. Cleland J, Moffat M, Small I. A qualitative study of stakeholder views of a communitybased anticipatory care service for patients with COPD. Prim Care Respir J 2012;21: 255-60. http://dx.doi.org/10.4104/pcrj.2012.00008
2. Seamark D, Blake S, Seamark $C$, et al. Is hospitalisation for COPD an opportunity for advance care planning? A qualitative study. Prim Care Respir J 2012;21:261-6. http://dx.doi.org/10.4104/pcrj.2012.00032

3. NICE UK. Services for people with chronic obstructive pulmonary disease; Accessed 29/06/12: Available from: http://publications.nice.org.uk/services-for-people-withchronic-obstructive-pulmonary-disease-cmg43/43-specifying-supportive-andpalliative-care-for-people-with-copd\#432-advance-care-planning.

4. Hansen E. Successful qualitative health research: a practical introduction. NSW, Australia: Allen and Unwin; 2006.

5. Schoen C, Osborn R, Squires D, Doty M, Pierson R, Applebaum S. New 2011 survey of patients with complex care needs in eleven countries finds that care is often poorly coordinated. Health Affairs 2011;30:2437-48. http://dx.doi.org/10.1377/ hlthaff.2011.0923

6. Health Issues Centre 2010. On my terms...alone at home with care needs: Improving choices. Health Issues Centre, Lincoln Centre for Ageing and Community Care Research, Council for the Ageing Victoria. Aged Care Branch Victorian Health Department, Melbourne, 2010.

7. While C, Duane F, Beanland C, Koch S. Self management of medicines by older people in the community: a person-centred guide to assessment. Melbourne: Royal District Nursing Service, 2011.

8. Mola E, De Bonis JA, Giancane R. Integrating patient empowerment as an essential characteristic of the discipline of general practice/family medicine. Eur J Gen Pract 2008;14(2):89-94. http://dx.doi.org/10.1080/13814780802423463

9. Bainbridge L, Nasmith L, Orchid C, Wood V. Competencies for interprofessional collaboration. Journal of Physical Therapy Education 2010;24(1):6-11.

10. Dean MM. End-of-life care for COPD patients. Prim Care Respir J 2008;17(1):46-50. http://dx.doi.org/10.3132/pcrj.2008.00007

11. Goeman DP, Hogan CD, Aroni RA, et al. Barriers to delivering asthma care: a qualitative study of general practitioners. Med J Aust 2005;183(9):457-60.

12. http://www.respectingpatientchoices.org.au/index.php (accessed 28th June 2012).

13. Lopez A, Shibuya K, Rao C et al. Chronic obstructive pulmonary disease: current burden and future projections. Eur Resp J 2006;27:397-41. http://dx.doi.org/ 10.1183/09031936.06.00025805

\title{
2012 and never been KISSed: we need to improve the care of children with asthma
}

\section{See linked article by Jonsson et al. on pg 276}

\section{${ }^{*}$ Andrew Bush ${ }^{\mathrm{a}}$, Louise Fleming ${ }^{\mathrm{b}}$}

a Professor of Paediatric Respirology, Imperial College, London, UK; and Consultant Paediatric Chest Physician, Royal Brompton Hospital, London, UK

b Clinical Senior Lecturer, Respiratory Paediatrics, Imperial College, London, UK

*Correspondence: Professor Andrew Bush, Department of Paediatric Respiratory Medicine, Royal Brompton Hospital, Sydney Street, London SW3 6NP, UK.

Tel: +44 (0)207351 8232 Fax: +44 (0)207 3518763

E-mail: a.bush@rbh.nthames.nhs.uk

'KISS' - 'Keep It Simple, Stupid' - is sound advice in virtually every clinical situation. In medical school, we focus on getting the basics right and doing the simple things well before rushing headlong into the expensive and elaborate. Asthma in children is common, is the subject of evidence-based guidelines, ${ }^{1}$ and in most cases just requires the KISS approach: get the diagnosis right; give an appropriate level of treatment; make sure the child and family know what it is all about, especially how to use the medication delivery device; and as far as possible eliminate trigger factors from the environment.

And yet, in this issue of the PCRJ, Jonsson et al. demonstrate not merely that the easy is not being done, but indeed, given the opportunity to seize the wrong end of the stick, primary care is doing this with assiduous attention! ${ }^{2}$ So not merely do they report a litany of sins of omission, but all practices had a nebuliser to treat asthma attacks - even though all the evidence is that metered-dose inhalers used with a spacer are at least as safe and effective as the nebulised route in all but the most severe attacks ${ }^{3}$ - and then only if the practice had oxygen available... However, two things must be stated immediately. Firstly, the authors are to be congratulated on performing this study and having the chutzpah to publish the results. Secondly, how many asthma clinics (primary, secondary or even tertiary) inside or outside Sweden would be confident in their performance if submitted to the same scrutiny? Certainly, our experience with really severe asthma is that in at least half of cases there is a need to get the basics right rather than infusing the latest toxic biological. 4,5

This having been said, the results are depressing. The authors studied a large number of children and showed that only a minority had received competent care. ${ }^{2}$ Most would acknowledge that 
environmental factors are important, but documentation of environmental tobacco smoke (14\%), pet exposure (30\%), and the indoor environment (5\%), was at best pitiful. The hallmark of asthma is airflow obstruction which varies spontaneously over time and with treatment, yet the vast majority had never performed even the simplest physiological test. Documentation of even the most basic aspect of patient education, namely checking the child could actually use the prescribed medication device, was also lamentable. Finally, even an asthma attack severe enough to merit the prescription of inhaled corticosteroids (ICS) only triggered 'education' but no inhaler checks and no measurement of pulmonary function. One expects asthma nurses to be more meticulous than doctors, (and certainly much more than professors!), but the results reported here reflect little credit on the nurses either. True, access to an asthma nurse meant that the child was more likely to have spirometry performed, but this was the only one of 16 comparisons which showed any difference scarcely a powerful endorsement of the role of the asthma nurse.

One problem with interpreting these data is that children as young as six months were lumped together with school age children, and possibly that these interventions had been done but not documented - the latter a charitable view to which we do not subscribe. In future papers it might be better to avoid this, given the evidence that many young children will have pure episodic viral wheeze, which has completely different pathophysiology and management, in particular pharmacological. ${ }^{6-9}$ Having said this, it cannot be said to be good practice to give a parent of a child of any age an inhaler without showing them how to use it.

So what can be done about this? We could perhaps learn from the US Cystic Fibrosis (CF) Foundation's Quality Improvement program, which has been used to drive up standards in underperforming centres. ${ }^{10}$ They published individual clinic data on spirometry and body mass index (BMI) to identify those clinics who thought they were doing well but were not, and then encouraged a process of selfexamination and change to raise standards. They had the advantage of knowing that both spirometry and BMI are (a) easy to measure, and (b) directly related to prognosis. This was no mere paper exercise, but led to genuine year-on-year improvements. Should primary care (and for that matter, secondary and tertiary care) be doing the same for asthma?

If we are going to attempt quality improvement, what should we measure? Even more fundamental, what do you have to provide before you can call yourself an asthma clinic? As far as we are aware, this pretty fundamental question has never been answered or even been acknowledged as a question worth answering. One obvious difference between CF and paediatric asthma is the difficulty of finding things to measure which can be done easily and which relate to prognosis in asthma. Possibly the number of children collecting more than one canister of short-acting $\beta_{2}$-agonist per month might be one, but probably there are very few of these. ${ }^{11}$ So unfortunately and distastefully, the answer will likely have to concentrate on process not outcome. But unlike our political masters, we should at least try to ensure that the processes we look at bear some relationship to a good outcome.

Table 1 is therefore a non-evidence-based attempt to define what an asthma clinic in any developed world context should provide, together with benchmarks against which care could be measured; none requires expensive apparatus or is very time-consuming, and the use of computerised proformas and databases would hopefully ensure that what had been done had been documented, thus allowing a ready audit of performance. Noteworthy is that we have not specified who should see the children in the clinic. There is no evidence-based reason why a doctor and a nurse should be involved - and to judge from the data of Jonsson et al., a folie a deux is more expensive and equally ineffective as a folie a un... We have also stayed neutral on doctor versus nurse-led clinics; there is no doubt which is likely cheaper. Of course, it could be argued that there is no evidence that any children suffer harm from neglect of these aspects of care, but these criteria will never be subject to a randomised controlled trial. We wonder what choice we would make for our own children between a clinic which offers all these aspects of care as against one

Table 1. Possible requirements for a paediatric asthma clinic

\begin{tabular}{|c|c|c|}
\hline Element of care & Measurement & Age group \\
\hline \multirow[t]{2}{*}{ Diagnosis } & Has the presence or absence of polyphonic wheeze been documented? & All \\
\hline & Has variable airflow obstruction been documented with physiological testing? & School age children \\
\hline \multirow[t]{2}{*}{ General Paediatric Care } & Are height and weight being measured regularly? & All \\
\hline & Are the data plotted on a growth chart? & All \\
\hline \multirow[t]{9}{*}{ Asthma Baseline Control } & $\begin{array}{l}\text { Has asthma control been documented using an appropriate questionnaire } \\
\text { at least every six months? }\end{array}$ & All \\
\hline & Has lung function been measured at least every six months? & School age children \\
\hline & Has inhaler technique been taught, and checked at least every six months? & All \\
\hline & Have tobacco related issues been discussed? & All \\
\hline & Has the home environment, including pet exposure, been discussed? & All, but especially school age children \\
\hline & How many canisters of $\beta_{2}$ agonists are being dispensed per month? & All \\
\hline & Does this number of canisters merit inhaled corticosteroid prescription? & $\begin{array}{l}\text { School age children, pre-school } \\
\text { children with multiple-trigger wheeze }\end{array}$ \\
\hline & What is the prescription pick-up rate of prophylactic medications? & $\begin{array}{l}\text { School age children, pre-school } \\
\text { children with multiple-trigger wheeze }\end{array}$ \\
\hline & $\begin{array}{l}\text { Are second opinions being sought at a guideline recommended level } \\
\text { of treatment? }\end{array}$ & All \\
\hline \multirow[t]{3}{*}{ Acute asthma attacks } & Are number of urgent contacts with medical care documented? & All \\
\hline & Are number of prednisolone bursts documented? & All \\
\hline & $\begin{array}{l}\text { Has basic asthma care been documented as having been reviewed after } \\
\text { a prednisolone burst (prescription uptake, inhaler technique, environment) }\end{array}$ & All \\
\hline
\end{tabular}


that offers none of them.

Over-diagnosis of asthma is a concern worldwide; one recent systematic study showed that $30 \%$ of adults were wrongly diagnosed..$^{12}$ Of course there is no diagnostic test for asthma, but if wheeze has never been heard, and variable airflow obstruction never demonstrated, then the physician should have heightened alertness for another diagnosis (in particular, that most difficult diagnosis of 'the normal child'). Measuring growth and recording the results is not merely good practice, but the only way of detecting faltering growth due to uncontrolled asthma, excessive ICS dosages or a coincidental diagnosis. The other two sections in our Table relate to on-going asthma care. The basic components of assessing baseline control of asthma are well rehearsed in guidelines. The response to acute deterioration of asthma is largely ignored, and almost uniformly feeble. Asthma 'exacerbations' are not benign, but are associated with an accelerated rate of lung function decline in children not treated with $\mathrm{ICS}^{13}$ (though note that only half of those with an exacerbation bad enough to be given nebulised therapy were then given ICS; this may have been a correct decision in pre-schoolers with episodic viral wheeze). Elsewhere it has been argued that a better term would be 'asthma lung attacks', ${ }^{14,15}$ and that such an attack should prompt a focussed re-appraisal of all aspects of management. Unfortunately there is no evidence that this ever happened in the present study. ${ }^{2}$

So how have we got into the position of treating a really common condition like asthma with expensive medications - the cumulative cost of which runs to billions of euros - without really having any idea of who is doing a good job and who is not? And what are we going to do about it? Perhaps the fact that paediatric asthma is common, and usually appears to be more of a 'nuisance', has led us to become blasé about the condition. So we need a wake-up call; children have impaired quality of life because of asthma, some still die from asthma, ${ }^{16}$ and childhood asthma is a risk factor for later COPD. ${ }^{17}$ Asthma UK estimate that $75 \%$ of asthma admissions are avoidable, and we would add the corollary, only if you try to avoid them. Children with asthma deserve proper care, and they and their families deserve to have information on which to base an informed choice of where to access care. We have here proposed the sort of care that should be mandated, and information which ought to be out there for families to access. Others might have different criteria, but we hope most would believe that some sort of criteria should be developed.

So, Jonsson et al. ${ }^{2}$ have done all of us a signal service in highlighting how badly we are looking after children with asthma. We must now put our own house in order before order is imposed from on high. This paper should stimulate the asthma community (children, families, and healthcare professionals) to take the following steps, with sticks and carrots to ensure compliance:

- Set standards of care which are realistic, measurable, and deliverable

- Audit individual clinics against these standards

- Make the results publicly available

So let's all KISS!
Conflicts of interest $A B$ is funded and supported by the NIHR Respiratory Disease Biomedical Research Unit at the Royal Brompton and Harefield NHS Foundation Trust and Imperial College London. The views expressed in this publication are those of the authors and not necessarily those of the NHS, The National Institute for Health Research or the Department of Health.

Commissioned article; not externally peer-reviewed; accepted 14th June 2012; online 26th July 2012

(C) 2012 Primary Care Respiratory Society UK. All rights reserved http://dx.doi.org/10.4104/pcrj.2012.00062

Prim Care Respir J 2012; 21(3): 242-244

\section{References}

1. British Thoracic Society, Scottish Intercollegiate Guidelines Network (SIGN). British guideline on the management of asthma. Thorax 2003;58(Suppl I):i1-94.

2. Jonsson M, Egmar A-C, Kiessling $A$, et al. Adherence to national guidelines for children with asthma at primary health centres in Sweden: potential for improvement. Prim Care Respir J 2012;21:276-82.

http://dx.doi.org/10.4104/ pcrj.2012.00051

3. Cates CJ, Crilly JA, Rowe BH. Holding chambers (spacers) versus nebulisers for betaagonist treatment of acute asthma. Cochrane Database Syst Rev 2006;(2):CD000052

4. Bracken MB, Fleming $L$, Hall $P$, et al. The importance of nurse led home visits in the assessment of children with problematic asthma. Arch Dis Child 2009;94:780-4. http://dx.doi.org/10.1136/adc.2008.152140

5. Bush A, Saglani S. Management of severe asthma in children. Lancet 2010;376: 814 25. http://dx.doi.org/10.1016/S0140-6736(10)61054-9

6. Brand $\mathrm{PL}$, Baraldi $\mathrm{E}$, Bisgaard $\mathrm{H}$, et al. Definition, assessment and treatment of wheezing disorders in preschool children: an evidence-based approach. Eur Respir $J$ 2008;32:1096-110. http://dx.doi.org/10.1183/09031936.00002108

7. Saglani S, Payne DN, Zhu J, et al. Early Detection of Airway Wall Remodelling and Eosinophilic Inflammation in Preschool Wheezers. Am J Respir Crit Care Med 2007; 176: 858-64. http://dx.doi.org/10.1164/rccm.200702-2120C

8. Sonnappa S, Bastardo CM, Wade A, et al. Symptom-pattern and pulmonary function in preschool wheezers. J Allergy Clin Immunol 2010;126:519-26. http://dx.doi.org/10.1016/j.jaci.2010.04.018

9. Sonnappa S, Bastardo CM, Saglani S, Bush A, Aurora P. Relationship between past airway pathology and current lung function in preschool wheezers. Eur Respir J 2011; 38:1431-6. http://dx.doi.org/10.1183/09031936.00164910

10. Quon BS, Goss CH. A story of success: continuous quality improvement in cystic fibrosis care in the USA. Thorax 2011;66:1106-8. http://dx.doi.org/10.1136/ thoraxjnl-2011-200611

11. Spitzer WO, Suissa S, Ernst $P$, et al. The use of beta-agonists and the risk of death and near death from asthma. N Engl J Med 1992;326:501-06 http://dx.doi.org/ 10.1056/NEJM199202203260801

12. Aaron SD, Vandemheen $\mathrm{KL}$, Boulet $\mathrm{LP}$, et al; Canadian Respiratory Clinical Research Consortium. Overdiagnosis of asthma in obese and non-obese adults. CMAJ. 2008;179:1121-31. http://dx.doi.org/10.1503/cmaj.081332

13. O'Byrne PM, Pedersen S, Lamm CJ, Tan WC, Busse WW; START Investigators Group. Severe exacerbations and decline in lung function in asthma. Am J Respir Crit Care Med 2009;179:19-24. http://dx.doi.org/10.1164/rccm.200807-11260C

14. FitzGerald JM. Targeting lung attacks. Thorax 2011;66:365-6. http://dx.doi.org/10.1136/thx.2010.156760

15. Bush A, Pavord I. Following Nero: fiddle while Rome burns, or is there a better way? Thorax 2011;66:367. http://dx.doi.org/10.1136/thx.2011.160861

16. Anagnostou K, Harrison B, lles R, Nasser S. Risk factors for childhood asthma deaths from the UK Eastern Region Confidential Enquiry 2001-2006. Prim Care Respir J 2012;21(1):71-7. http://dx.doi.org/10.4104/pcrj.2011.00097

17. Svanes $C$, Sunyer J, Plana E, et al. Early life origins of chronic obstructive pulmonary disease. Thorax 2010;65:14-20 . http://dx.doi.org/10.1136/thx.2008.112136 